\title{
PENGENALAN PUPUKORGANIK CAIR LIMBAH PASAR TRADISIONAL SEBAGAI MEDIA TUMBUH RUMPUT SETARIA (Setaria sphacelata) DI KELURAHAN MERSI, PURWOKERTO UTARA
}

\author{
Hesti Nurlaeli \\ STKIP Darussalam Cilacap \\ E-mail: hestimutiara17@gmail.com
}

\begin{abstract}
ABSTRAK. Pengabdian masyarakat merupakan salah satu drai Tri Dharma Perguruan Tinggi yang harus dilakukan oleh seorang dosen. Saat ini jenis pupuk kimia dan penggunaannya sudah banyak digunakan tanpa melihat resiko yang akan dihadapi kelak. Adapun solusi yang dapat dilakukan adalah dengan menggunakan pupuk organik yang lebih ramah lingkungan. Salah satu jenis pupuk yang dapat digunakan adalah pupuk organik cair limbah pasar tradisional yang telah di produksi di Pengelolaan Sampah Organik, Kelurahan Merci, Purwokerto Utara.

Metodologi dalam pengabdian masyarakat ini adalah dengan melakukan penanaman rumput Setaria sp., dengan menggunakan pupuk organik cair limbah pasar tradisional. Penanaman dilakukan sampai \pm 50 hari untuk dipanen. Selama proses tanam sampai panen, dilakukan pengamatan pertumbuhan rumput Setaria sp., dengan melihat tinggi, kanopi, jumlah anakan dan jumlah daun. Setelah melakukan penanaman sampai pemanenan, diukur tumbuh kembang Setaria sp., mengalami pertumbuhan dan perkembangan dengan baik. Seperti padi, rumput setaria tumbuh tinggi ke atas, jumlah kanopi yang melengkung, jumlah anakan dan jumlah daun yang banyak. Hal ini menunjukkan bahwa pupuk organik cair mampu menjadi media tumbuh Setaria sp., yang baik dan pupuk organik cair ini bisa dikenalkan lagi untuk menjadi media tumbuh jenis rumput lain yang berfungsi sebagai pakan ternak ruminansia. Meskipun hasil pertumbuhan ini tidak menunjukkan signifikan yang berarti. Dapat disimpulkan bahwa: 1) pupuk organik cair limbah pasar tradisional mampu menjadi media yang cukup baik dengan rumput Setaria sp., walaupun dalam hasil pertumbuhan rumput Setaria belum menunjukkan perubahan yang signifikan. 2) pupuk organik cair limbah pasar tradisional mempunyai kelebihan yang sama sebagai pupuk organik yang baik digunakan daripa penggunaan pupuk kimia yang dapat mencemari lingkungan
\end{abstract}

Kata kunci: Pupuk organik cair; Setaria spcahelata; pertumbuhan

ABSTRACT. Community service is one of the drafts of the Tri Dharma of Higher Education that must be done by a lecturer. Currently the type of chemical fertilizer and its use have been widely used without looking at the risks that will be faced later. The solution that can be done is to use organic fertilizers that are more environmentally friendly. One type of fertilizer that can be used is traditional market liquid waste organic fertilizer that has been produced in Organic Waste Management, Merci Village, North Purwokerto.

The methodology in community service is by planting Setariasp grass, using traditional market liquid waste organic fertilizer. Planting is done up to \pm 50 days to be harvested. During the process of planting to harvest, observations of the growth of Setaria sp. Grass were observed by looking at the height, canopy, number of tillers and number of leaves. After planting until harvesting, measured the growth of Setaria sp., Experienced good growth and development. Like rice, setaria grass grows high up, the number of canopies is curved, the number of tillers and the number of leaves is large. This shows that liquid organic fertilizer is capable of being a good medium for growing Setariasp and this liquid organic fertilizer can be introduced again to become a growing medium for other types of grass that function as ruminant feed. Although the results of this growth did not show significant significance. It can be concluded that: 1) traditional market liquid organic fertilizer can be a good medium with Setariasp grass, although the results of Setaria grass growth have not shown significant changes. 2) traditional market liquid organic fertilizer has the same advantages as organic fertilizer which is good to use from the use of chemical fertilizers that can pollute the environment

Key words: Liquid organic fertilizer,Setaria sphacelata, growth

\section{PENDAHULUAN}

Sampah atau limbah adalah bahan yang tidak berguna, tidak digunakan atau bahan yang terbuang sebagai sisa dari suatu proses (Moerdjoko, 2002). Limbah sayur-sayuran merupakan bahan buangan yang biasanya dibuang secara open dumping tanpa pengelolaan lebih lanjut sehingga akan meninggalkan gangguan lingkungan dan bau tidak sedap. Limbah sayuran ini mempunyai kandungan gizi rendah, yaitu protein kasar sebesar 1-1,5\% dan serat kasar 5-38\% (Afifudin, 2011). Limbah sayuran merupakan salah satu limbah organik.

Limbah organik adalah limbah yang dihasilkan dari bahan-bahan hayati yang dapat didegradasi oleh mikroba atau bersifat biodegradable. Limbah organik sendiri dibagi menjadi limbah organik basah dan limbah organik kering. Istilah limbah organik basah dimaksudkan limbah yang mempunyai kandungan air yang cukup tinggi, contohnya kulit buah dan sisa sayuran. Sedangkan limbah organik kering adalah limbah yang mempunyai kandungan air rendah, contohnya kayu atau ranting dan dedaunan kering (Cahya, 2009).

Besarnya komponen limbah yang dapat didekomposisi merupakan sumber daya yang cukup potensial sebagai sumber humus, unsur haramakro dan mikro, dan sebagai soil conditioner.Limbah dapat juga sebagai faktor pembatas karena kandungan logam-logam berat, senyawa organikberacun dan patogen, pengomposan dapat menurunkan pengaruh senyawa organik beracundan patogen terhadap lingkungan (Yuwono, 2006).Salah satu 
penanganan limbah organik yangefektif adalah mengolahnya sebagai pupukorganik.

Bahan organik tidak dapat langsung digunakan atau dimanfaatkan oleh tanaman karena perbandingan $\mathrm{C} / \mathrm{N}$ dalam bahan baku tersebut relatif tinggi atau tidak sama dengan $\mathrm{C} / \mathrm{N}$ tanah. Nilai $\mathrm{C} / \mathrm{N}$ tanah sekitar 10-12. Apabila bahan organik mempunyai kandungan $\mathrm{C} / \mathrm{N}$ mendekati atau sama dengan $\mathrm{C} / \mathrm{N}$ tanah maka bahan tersebut dapat digunakan atau diserap tanaman. Prinsip pengomposan adalah menurunkan $\mathrm{C} / \mathrm{N}$ rasio bahan organik sehingga sama dengan tanah $(<20)$. Dengan semakin tingginya $\mathrm{C} / \mathrm{N}$ bahan maka proses pengomposan akan semakin lama karena $\mathrm{C} / \mathrm{N}$ harus diturunkan (Dieya, 2013). Proses pengomposan anaerobik berjalan tanpa adanya oksigen. biasanya, prosesnya dilakukan dalam wadah tertutup sehingga tidak ada udara yang masuk (hampa udara). Proses pengomposan ini melibatkan mikroorganisme anaerob untuk membantu mendekomposisi bahan yang dikomposnya. Bahan baku yang dikomposkan secara anaerob biasanya berupa bahan organik yang berkadar air tinggi (Elmi et al., 2012).

Pengomposan anaerobik akan menghasilkan gas metan $\left(\mathrm{CH}_{4}\right)$, karbondioksida $(\mathrm{CO} 2)$, dan asam organik yang memiliki bobot molekul rendah seperti asam asetat, asam propionat, asam buirat, asam laktat, dan asam suksinat. Gas metan bisa dimanfaatkan sebagai bahan bakar alternatif (biogas). Sisanya berupa lumpur yang mengandung bagian padatan dan cairan. Bagian padatan ini yang disebut kompos. Namun, kadar airnya masih tinggi sehingga sebelum digunakan harus dikeringanginkan, sedangkan bagian cairannya dapat digunakan sebagai pupuk organik cair (Esther, 2009). Kandungan bahan kimia di dalampupuk organic cair tersebut maksimum 5\%. Penggunaan pupuk cair memiliki beberapa keuntungan yaitu: 1) pengaplikasiannya lebih mudah jika dibandingkan dengan pengaplikasian pupuk organik padat. 2) unsur hara yang terdapat di dalam pupuk cair terdapat dalam pupuk organik padat. 3) pencampuran pupuk cair organik dengan pupuk organik padat dapat mengaktifkan unsur hara yang ada dalam pupuk organik padat tersebut (Endang, 2008).

Kelebihan dari pupuk organik ini adalah dapat secaracepat mengatasi defesiensi hara, tidak bermasalah dalam pencucian hara, dan mampu menyediakan hara secara cepat. Dibandingkan dengan pupuk cair anorganik, pupuk organik cair umumnya tidak merusak tanah dan tanaman walaupun digunakan sesering mungkin. Hal ini sesuai dengan pendapat Setiyo et al., (20122), bahwa penggunaan pupuk organik memiliki peranan dalam kesuburan tanah, karena penggunaan pupuk pada tanaman pangan dan non pangan dapat memperbaiki sifat fisik, kimia, maupun biologi tanah. Selain itu, pupuk ini juga memiliki bahan pengikat, sehingga larutan pupuk yang diberikan oleh tanaman (Bella, 2013). Pupuk organik cair (POC) dalam proses pembuatannya memerlukan waktu yang lebih cepat dari pupuk organik padat dan penerapannya di pertanian yakni tinggal di semprotkan ke tanaman (Dieyna, 2013).

Hijauan pakan merupakan pondasi dalam pengembangan pertenakan ruminansia sebab pelaksanaan perencanaan awal adalah ketersediaan hijauan pakan dalam bentukhamparan tanaman sumberhijauan pakan(Hendarto dan Suwarno, 2005). Ketersediaannya pada dasarnya menentukan tingkat produksi ternak. Tanaman rerumputan merupakan salah satu penyedia hijauan pakan dan harus tersedua terlebih dahulu sebelum ternak ruminansia didatangkan ke lokasi peternakan (Gordeyasemmas et al., (2007) dalam Hendarto dan Suwarno (2005)). Rumput unggul dalam budidaya sebagai sumber hijauan pakan telah nampak tampilan pertumbuhan dan produksinya setelah dipanen atau mengalami pertumbuhan.

Pakan ternak ruminansia terdiri dari pakan hijauan, konsentrat, vitamin dan mineral sebagai suplemen. Hijauan yang biasa digunakan sebagai pakan pada usaha peternakan rakyat di pedesaan adalah rumput lapangan dan hasil samping pertanian, serta beberapa rumput introduksi sebagai rumput unggulan. Hasil sampingan pertanian yang sering digunakan adalah jerami padi, jerami jagung, jerami kedelai, jerami sorgum, daun ubi jalar, daun ubi kayu dan pucuk tebu, sedangkan bahan baku konsentrat yang sering digunakan adalah dedak padi, geplek, bungkil kelapa, bungkil kelapa sawit dan lain-lain.

Masalah utama dalam peningkatan produktivitas ternak adalah sulitnya menyediakan pakan secara berkesinambungan baik jumlah maupun kualitasnya. Faktor penting yang harus diperhatikan dalam peningkatan produktivitas ternak adalah ketersediaan pakan yang mencukupi secara kualitas dan kuantitas. Selain itu juga diperlukan pupuk yang bisa digunakan untuk kelangsungan hidup rumput sebagai pakan ternak, agar masyarakat dapat menanam rumput pakan ternaknya tanpa harus bersusah mencari rumput, akan menjadi efisien jika setiap peternak menanam rumputnya di samping kandang ternaknya. Pupuk akan berperan untuk menentukan pertumbuhan dan produksi rumput pakan ternak yang berhubungan dengan tingkat kesuburan tanah, agar perumbuhan tanaman tersebut tetap baik.

Setaria sphacelata merupakan salah satu jenis tanaman rumput pakan ternak dengan tingkat produksi tinggi. Selain itu tanaman rumput ini, merupakan tanaman pakan yang sangat palatabel, berproduksi tinggi mencapai 31 ton/ha/tahun (Hacker, 1992 dalam Wiswasta, 2013), memiliki kandungan Protein Kasar (PK) pada hijauan yang mencapai 9,5\%,31,7\% serat kasar, 2,5\% ekstrak eter, $45,2 \%$ BETN, 11,1\% abu dan 7\% asam oksalat. (Hartadi et al., 1990) menyatakan bahwa rumput Setaria sp., tumbuh tegak, berumpun lebat, dengan tinggi mencapai $2 \mathrm{~m}$, dan tahan terhadap kering, sehingga dapat menjadi sumber pakan pada musim kemarau terutama di Nusa Tenggara Timur (NTT). Dalam penelitian Eroni dan Aregheore (2006), melaporkan bahwa sapi perah dengan bobot tubuh 430-447 kg, mampu mengkonsumsi rumput Setaria sp., pada ternak adalah $10,5 \mathrm{~kg}$ bahan kering $(\mathrm{BK}) /$ hari. 
Berdasarkan latar belakang di atas, dapat diberi judul "Pengenalan Pupuk Organik Cair Limbah Pasar Tradisional Sebagai Media tumbuh Rumput Setaria (Setaria sphacelata) Di Kelurahan Mersi, Purwokerto Utara". Dari judul dan latar belakang tersebut maka dapat dirumuskan masalah yaitu apakah penggunaan pupuk organik cair limbah pasar tradisional ini mampu menjadi media pupuk yang baik bagi rumput Setaria sp., kemudian tujuan kegiatan pengabdian masyarakat ini adalah untuk mengenalkan pupuk organik cair limbah pasar tradisional sebagai media tumbut tumput Setaria sphacelata di kelurahan Mersi Purwokerto.

\section{METODE}

Metodologi dalam pengabdian masyarakat ini adalah dengan melakukan penanaman rumput Setaria sp., dengan menggunakan pupuk organik cair limbah pasar tradisional. Penanaman dilakukan sampai \pm 50 hari untuk dipanen. Selama proses tanam sampai panen, dilakukan pengamatan pertumbuhan rumput Setaria sp., dengan melihat tinggi, kanopi, jumlah anakan dan jumlah daun. Penulis melakukan wawancara dengan penanggung jawabtempat pengelolaan limbahyang ada di Kelurahan Mersi, Purwokerto Utara, namanya bapak Satiman. Beliau menjelaskan bahwa ditempat pengelolaan sampah tersebut, selain mengumpulkan sampah/limbah yang dapat di daur ulang lalu dijual, contonya botol bekas minuman. Tempat pengelolaan sampah tersebut melakukan pembuatan biogas, dimana hasil gas metan yang diperoleh itu kemudian dialirkan ke rumah-rumah tetangga sekitar tempat pengeloaan limbah tersebut. Warga di sekitar merasa sangat terbantu dan menjadi ramah lingkungan karena menggunakan bahan bakar dari bahan alami. Selain itu penggunaan gas metan ini lebih hemat dibanding bahan bakar jenis gas LPG atau bahan bakar minyak.

Selain menghasilkan gas metan, hasil biogas dari limbah sayuran yang di peroleh dari pasar-pasar yang ada di Purwokerto ini yaitu pupuk organik cair yang sudah di kemas dalam sebuah botol dan berlabel dengan kompisisi dari pupuk cair organik ini. namun untuk penjualannya dan pemakaian pupuk untuk diaplikasikan ke tanaman, secara ilmiah belum pernah diteliti. Warga yang membeli pupuk organik cair tersebut sebesar 15 ribu per botol. Dengan demikian penulis ingin mengenalkan produk pupuk organik cair ini bahwa dapat digunakan sebagai media tumbuh rumput Setaria, dimana rumput Setaria adalah salah satu jenis pakan yang berkualitas tinggi sebagai pakan ternak ruminansia. Adapun langkah-langkah yang dilakukan penulis setelah melakukan wawancara dengan kepala pengelola sampah di Kelurahan Mersi, Purwokerto Utara.

1. Tahap persiapan pengadaan benih rumput Setaria. Setelah wawancana dengan bapak Satiman, benih Setaria sp., dilakukan cara sobekan(pols) seperti pada benih padi. Benih di potong pendek yang nanti akan di tanam di petak-petak tanah

2. Pupuk organik cair disiapkan lalu diencerkan terlebih dahulu dnegan air, setelah benih Setaria sp., di tanam maka dilakukan pemupukan sekali, setelah 7 hari penanaman benih.

3. Detiap hari tiap pagi dan sore, Setaria sp., disiram dan

4. Pada usia 50 hari, Setaria sp., siap dipanen yaitu dengan mengukur tinggi, jumlah daun, kanopi Setaria sp., dan jumlah anakan Setaria sp.,

5. Data pengukuran, dianalisis dengan uji statistik SPSS for windows, selanjutnya diuji dengan uji One way Anova untuk ada tidaknya pengaruh perbedaan pemberian pupuk organik cair terhadap produktivitas tumbuhan Setaria sp., setelah itu data diuji dengan uji LSD (Least Significant Defference) untuk melihat perbedaan yang lebih significant pada pemberian pupuk organik cair ke tumbuhan Setaria sp.,

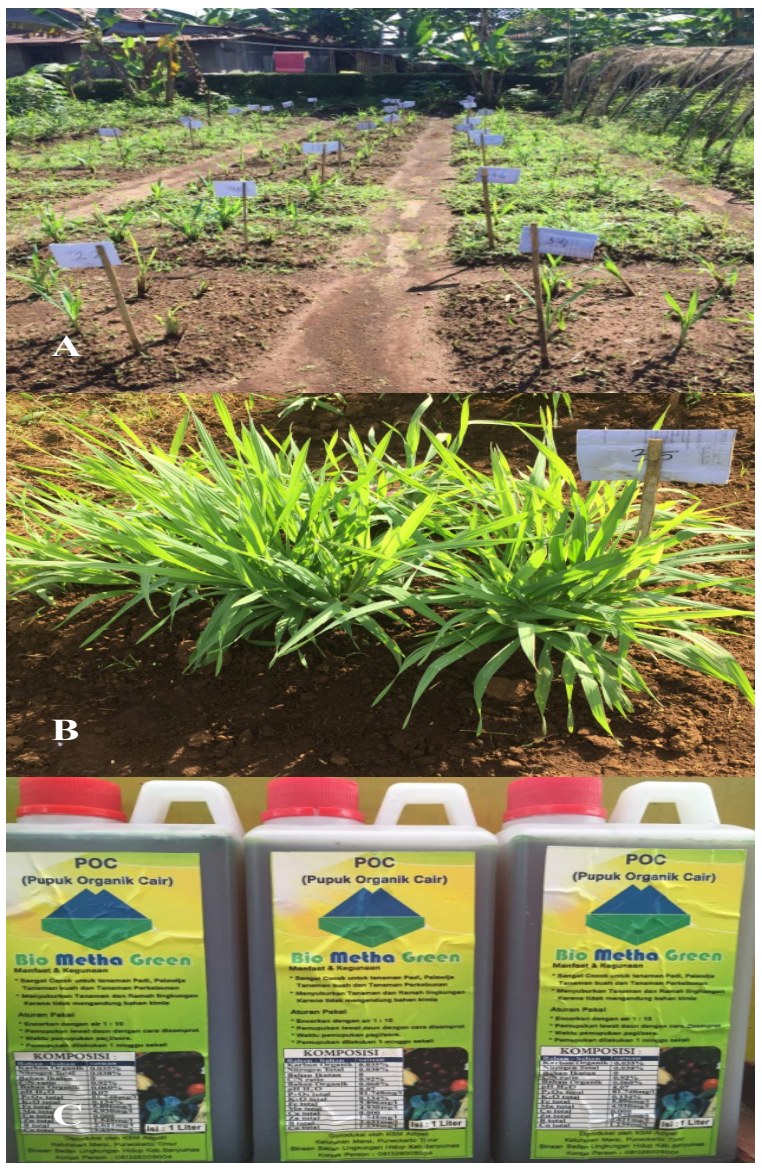

Gambar 1. Tanaman Setaria dengan pupuk organik cair. A) saat awal tanam, b) saat pertumbuhan selama masa tanam dan siap panen, C) POC limbah pasar tradisional

\section{HASIL DAN PEMBAHASAN}

Pertumbuhan adalah sintesis protoplasma, biasanya diikuti oleh perubahan bentuk dan penambahan massa yang dapat lebih besar dari penambahan plasma itu. Pengertian pertumbuhan membutuhkan ukuran secara tepat dan dapat dibaca dengan bentuk kuantitatif yang 
dapat diukur. Analisis pertumbuhan merupakan suatu cara untuk mengikuti dinamika fotosintesis yang diukur oleh produksi bahan kering. Pertumbuhan tanaman dapat diukur tanpa mengganggu tanaman, yaitu dari ukuran panjang, lebar atau luas, pertambahan massa atau berat (Bidwell, 1979). Sedangkan menurut Noggle dan Fritz (1983) pertumbuhan dapat ditunjukkan dengan meningkatnya tinggi tanaman, panjang, lebar, dan luasdaun, serta berat kering masing-masing organ yang meliputi akar, batang, daun dan buah; jumlah sel dan konsentrasi kandungan kimia tertentu, yaitu asam nukleat nitrogen terlarut, lipid, karbohidrat dalam jaringan dan organ.

Setelah melakukan penanaman sampai pemanenan, diukur tumbuh kembang Setaria sp., mengalami pertumbuhan dan perkembangan dengan baik. Seperti padi, rumput setaria tumbuh tinggi ke atas, jumlah kanopi yang melengkung, jumlah anakan dan jumlah daun yang banyak. Hal ini menunjukkan bahwa pupuk organik cair mampu menjadi media tumbuh Setaria sp., yang baik dan pupuk organik cair ini bisa dikenalkan lagi untuk menjadi media tumbuh jenis rumput lain yang berfungsi sebagai pakan ternak ruminansia. Meskipun hasil pertumbuhan ini tidak menunjukkan signifikan yang berarti (tabel 1). Tanaman Setaria sp., sebagai kontrol menunjukkan pertumbuhan yang baik tanpa penggunaan pupuk organik cair, sama dengan tanaman Setaria sp. dengan pemberian pupuk organik cair ini terhadap tinggi tanaman, kanopi, jumlah anakan dan jumlah daun.

Beberapa alasan yang bisa menjadi dasar hal ini terjadi, dimana POC limbah pasar tradisional belum berpengaruh kuat terhadap pertumbuhan Setaria sphacelata yaitu:

1. Keadaan tanah yang terdapat di lahan untuk penanaman Setaria sp., ternyata mempunyai hara $\mathrm{N}$ yang cukup tinggi yaitu 49,35 ppm, 0,198 ppm $\mathrm{P}_{2} \mathrm{O}_{5}$ tersedia, dan 0,496 me $\% \mathrm{~K}_{2} \mathrm{O}$ tersedia, sedangkankandungan hara POC limbah pasar tradisional adalah Carbon Organik (0.035\%), Nitrogen total (0.038\%), Bahan ikutan (0),
$\mathrm{C} / \mathrm{N}$ ratio (0.92\%), $\mathrm{pH} \mathrm{H} \mathrm{H}_{2} \mathrm{O}(8.07), \mathrm{P}_{2} \mathrm{O}_{5}$ total (81.748 $\mathrm{mg} / \mathrm{l}), \mathrm{K}_{2} \mathrm{O}$ total $(0.134 \%)$, Fe total $(5.896 \mathrm{mg} / \mathrm{l}), \mathrm{Mn}$ total $(4.930 \mathrm{mg} / \mathrm{l}), \mathrm{Cu}$ total $(0.000), \mathrm{Zn}$ total $(1.548$ $\mathrm{mg} / \mathrm{l})$, Co total $(1.239 \mathrm{mg} / \mathrm{l})$. Dengan demikian ketersediaan N, P, K yang dibutuhkan oleh Setaria sp., untuk pertumbuhan dalam jumlah yang hampir sama.

2. Frekuensi POC limbah pasar tradisional yang sekali dalam tujuh hari ternyata belum mampu meningkatkan pertambahan tinggi tanaman Setaria sp., unsur hara yang tersedia mempengaruhi pertumbuhan tanaman. Purbajanti (2013) menyatakan bahwa jumlah unsur hara yang dibutuhkan oleh tanaman maupun ternak bergantung pada fungsi metabolik dan bervariasi tergantung jenis unsur dan spesies tanaman. Gardner et al., (2008) menjelaskan bahwa nitrogen dan phosphor sangat penting dalam meningkatkan pertumbuhan vegetatif tanaman. Adanya N yang cukup menyebabkan terjadinya pembesaran dan pemanjangan sel tanaman yang berdampak pada pertumbuhan tanaman sedangkan phosphor merupakan unsur penyusun inti sel dan sangat penting dalam proses pembelahan sel yang akan mempercepat pertumbuhan tanaman.

3. Jarak tanam yang sama pada setiap unit tanaman. Menurut Muhakha et al., (2013)menyatakan bahwa bila ruang tumbuh tanaman dan usnur hara cukup tersedia dalam tanah sesuai dengan kebutuhan tanaman maka akan semakin banyak terbentuk individu baru. Selian itu pemberian pupuk dilakukan pada pukul 16.00, dimana saat itu masih terdapat sinar matahrii yang memungkinkan terjadinya penguapan unsur hara dalam pupuk cair terutama N. Sehingga jumlah unsur hara yang dimanfaatkan untuk pertumbuhan tanaman menjadi relatif sama. Pengaruh yang tidak berbeda nyata tersebut disebabkan oleh unsur NPK tanah yang ada pada pupuk cair belum mampu dimanfaatkan oleh tanaman Setaria sp., selain itu yang disebabkan oleh tidak berbedanya media digunakan dalam penelitian ini terutama unsur $\mathrm{pH}$ tanah.

Tabel 1. Hasil Analisis LSD Pertumbuhan Rumput Setaria sphacelata

\begin{tabular}{|c|c|c|c|c|c|c|}
\hline & & Sum of Squares & Df & Mean Square & $\mathrm{F}$ & Sig. \\
\hline \multirow[t]{3}{*}{ Tinggi } & Between Groups & 303.349 & 5 & 60.670 & 1.212 & .328 \\
\hline & Within Groups & 1501.998 & 30 & 50.067 & & \\
\hline & Total & 1805.347 & 35 & & & \\
\hline \multirow[t]{3}{*}{ kanopi } & Between Groups & 412.832 & 5 & 82.566 & 1.022 & .422 \\
\hline & Within Groups & 2422.519 & 30 & 80.751 & & \\
\hline & Total & 2835.351 & 35 & & & \\
\hline \multirow[t]{3}{*}{ anakan } & Between Groups & 47.099 & 5 & 9.420 & 1.023 & .422 \\
\hline & Within Groups & 276.120 & 30 & 9.204 & & \\
\hline & Total & 323.219 & 35 & & & \\
\hline \multirow[t]{3}{*}{ jumlahdaun } & Between Groups & 2736.496 & 5 & 547.299 & 1.648 & .178 \\
\hline & Within Groups & 9962.232 & 30 & 332.074 & & \\
\hline & Total & 12698.728 & 35 & & & \\
\hline
\end{tabular}


4. Jumlah daun yang banyak akan menyokong produksi hijauan segar yang diperoleh pada setiap perlakuan. Hasil jumlah daun ini dalam analisis SPSS tidak menunjukkan perbedaan signifikan, namun hal ini masih bisa ditingkatkan dengan cara membuat aplikasi strategi kombinasi pemupukan dengan dosis atau pola pemupukan lainnya. Menurut Hendarto (2013), berbagai strategi pengelolaan termasuk pemupukan dapat dilakukan untuk mendukung keberlanjutan keberadaan, kehidupan dan kesejahtaeraan manusia. Hasil penelitian ini walaupun terdapat perbedaan dari setiap perlakuan yang diberikan, namun pada dasarnya belum memberikan pengaruh pada parameter jumlah daun. Hal tersebut memperlihatkan bahwa semua perlakuan yang diberikan dianggap seragam, akan menampilkan kondisi relatif sama. Namun demikian Georgiadis (2007) menambahkan bahwa pada proses fotosintesis tanaman dan menghasilkan energi dapat dilakukan karena tanaman memanfaatkan unsur nitrogen dari dalam tanah, energi tersebut digunakan untuk pertumbuhan tanaman, seperti untuk menambah jumlah duan dari setiap rumpun tanaman.

\section{SIMPULAN}

Berdasarkan uriaian di atas dapat disimpulkan :

1. Pupuk organik cair limbah pasar tradisional mampu menjadi media yang cukup baik dengan rumput Setaria sp., walaupun dalam hasil pertumbuhan rumput Setaria belum menunjukkan perubahan yang signifikan.

2. Pupuk organik cair limbah pasar tradisional mempunyai kelebihan yang sama sebagai pupuk organik yang baik digunakan daripa penggunaan pupuk kimia yang dapat mencemari lingkungan

\section{DAFTAR PUSTAKA}

Afifudin. 2011. Pengaruh Berbagai Aktivator Terhadap C/N Ratio Kompos Kotoran. PernerbitCV Sinar Indah, Bogor.

Bella, S. 2013. Kompos. http://www.ilmualam.blogspot. com. Diakses tanggal 05 Desember 2017.

Bidwell, R.G.S. 1979. Plant Phisiology Second edition. New York: Mcmilln Publishing Co, Inc.

Cahaya, A. 2009. Pembuatan Kompos Dengan Limbah Pada Organik (Sampah Sayuran dan Ampas Tebu. Tugas Akhir Jurusan Teknik Kimia UNDIP: Semarang.

Dieyna. 2013. Analisis Kadar Air. http://mizuc.blogspot. com/2012/11/analisis-kadar-air.html. Diakses tanggal tanggal 05 Desember 2017.

Elmi, S., Ellyta, S., Riko, R. 2012. Pembuatan Pupuk Organik Cair Menggunakan Bioaktivator Biosca dan EM4. Prosiding STNK TOPI: Pekanbaru.
Endang, Y. 2008. Pengaruh Suhu dan C/N Ratio Terhadap Produksi Biogas Berbahan Baku Sampah. Skripsi S1 Jurusan teknologi Pertanian IPB: Bogor.

Eroni danAregheore E. 2006. Effect of Molasses at Different Levels in Yield of diary Cows Grazing Setaria Grass (Setaria sphacelata) Pasture in Fiji. The University of the South Pacific, Shcool of Agriculture and Food technology Animal Science Departmen, Alafua Campus, Private mail Bag, Apia, Samoa. J. Anim. Sci. 19 (10) : 1455-1463.

Esther, L.T. 2009. Studi tentang Kandungan Nitrogen Karbon (C) Organik dan $\mathrm{C} / \mathrm{N}$ dari Kompos Tumbuhan Kembang Bulan (Tithonia diversifolia). Skripsi. Departmen Kimia, fakultas Matematika dan Ilmu Pengetahuan Alam. Universitas Sumatera Utara: Medan.

Gardner F.P., Pearce R.B dan Mitchell R.L. 2008. Fisiologi Tanaman Budidaya. Terjemahan. UI Press: Jakarta.

Georgiadis, N.J. 2007. Savana Herbivore Dynamics In A Livestock-Dominated Landsape. II: Ecological, Conservation and Management Implication of Predator Restoration. Journal of Biological Conservation, 137 (3):2007-2012.

Hendarto, E dan Suwarno. 2005. Forage as a Post For The Environmental Construction of Ruminant Livestock Farming. Paper presented at The Internationa; SeminarofenvironmentConstructiob. 2nd International Seminar and Workshop on Ecological Architectureand Enviroment in The Tropics. LMB Center of education. Soegijapranat Catholic University. Semarang. Februari 2005.

Hendarto, E dan Suwarno. 2013. Pengaruh Kombinasi Antara Pupuk Kandang dan Urea Pada tampilan Aspek Pertumbuhan Tanaman Rumput Raja Pada Pemanenan Defoliasi Ke Empat. Jurnal Bionatura Ilmu hayati dan Fisik. Vol 15, No 2, (83-88).

Moerdjoko S, Widyatmoko, 2002, Menghindari, mengolah dan menyingkirkan sampah, Cet.1, PT. Dinastindo Adiperkasa Internasional, Jakarta.

Muhakka, Napoleon A, Isti'adah, H. 2013. Pengaruh Pemberian Asap Cair Terhadap Pertumbuhan Rumput Raja (Pennisetum purpureophoides). Prosiding Seminar Nasional Lahan Suboptimal 2014, Palembang 26-27 September 2014 ISBN : 979-587-529-9.

Noggle, G.R and Frits, G.J. 1983. Introduction Plant Physiology, Second Edition. New Jersey: Prentice Hall, Inc, Englewood Clifts.

Purbajanti E.D. 2013. Rumput dan Legum. Penerbit Graha Ilmu: Yogayakarta. 
Wiswasta. 2013. Pertumbuhan dan Hasil Hijauan Tanaman Rumput Setaria (Setaria sphacelata stapf) yang Dipengaruhi Nitrogen, Fosfor, Mikoriza Vesikulas Arbuskula (MVA) Azospirillum. Skripsi Universitas Mahasaraswati: Denpasar
Yuwono, T. 2006, Kecepatan Dekomposisi dan kualitas Kompos Sampah Organik, Jurnal Inovasi Pertanian. Vol. 4, No.2. 